\title{
Vehicle insurance: prospects of judicial dispute resolution
}

\author{
Olga Egorova
}

Russian State University of Justice, Novocheremushinskaya Str., 69, 117418 Moscow, Russia

\begin{abstract}
In the Russian Federation, the vehicle insurance sector is gaining more and more prevalence and importance, which is due not only to the annually increasing number of road accidents occurring, but also to the digitalization paradigm of the entire Russian society. Any interested person who has suffered damage has the intention to restore his rights, including property rights, which is not always possible at the pre-trial stage of the development of a vehicle insurance conflict. Despite attempts to legislatively reform the pre-trial procedure for resolving disputes in cases arising from the vehicle insurance contract aimed at increasing guarantees of the rights of consumers of financial services, the judicial procedure for resolving such disputes does not lose its relevance. The judicial protection of the consumer financial services rights reveals the issue of court interpretation of legal texts, in particular, the rules of insurance and the vehicle insurance contract concluded by the consumer of financial services with the insurer. In the texts of such agreements, financial organizations specify the types of insurance events that do not fall under the signs of an insured event, which is the basis for compensation for damage caused. The correctness of the consideration and resolution of the dispute actually depends on the correct interpretation of these legal texts.
\end{abstract}

\section{Introduction}

Vehicle insurance disputes dominate in the total volume of civil cases considered and resolved in the courts of the Russian Federation. For example, in cases of collection under vehicle insurance contracts in 2017, the amount of satisfied claims of the plaintiffs amounted to more than 33 billion rubles, in 2018 this sum exceeded 39 billion rubles at the same time, in the specified calendar year, the total number of relevant statements of claim considered by the courts of general jurisdiction of the Russian Federation was more than 293 thousand [1]. The significance of this category of civil cases is associated not only with the possibility of insurers (beneficiaries) receiving compensation for material damage received as a result of a road traffic accident, the number of which is increasing every year, but also with the possibility of compensation for harm to the life and health of its participants.

The applicable law of the Russian Federation provides compulsory civil liability insurance of motor vehicle owners and inland transport insurance, which are often called voluntary. Regulatory legal acts that make up the legal field of the vehicle insurance sphere, after their publication and implementation, were repeatedly subjected to legislative adjustments, trying to take into account the emerging Russian realities and comply with them, 
including the digital paradigm of society development. We are talking about the introduction of a simplified procedure for registration of a road traffic accident without authorized police officers, the introduction of electronic TPO (third-party only insurance) policies (E-TPO). Moreover, a significant legislative innovation in the field of resolving vehicle insurance conflicts is the introduction of a mandatory pre-trial procedure for their settlement by contacting the insured with a financial ombudsman, whose competence has been legislatively "filled" with powers for out-of-court (alternative) resolution of a vehicle insurance dispute. Despite the number of legislative definitions already introduced and their practical significance, normative work on further study and the feasibility of introducing other legal provisions in the field of vehicle insurance continues.

Definitely, all effective legal norms in substantive legislation have an impact on the procedural order of judicial review and resolution of vehicle insurance conflict. At the same time, it should take into account the increasing number of actions on abuse of rights, both on the part of insurance companies and policyholders. The former often intend to "understate' the real cost of the restoration damage to the insured's property damaged as a result of a road traffic accident, and the latter to unreasonably receive such compensation (for example, in the absence of valid contractual relations with the insurer, in the absence of a real insured event).

\section{Materials and Methods}

Insurance is an integral part of any economically developed society and occupies an important place in any area of human life. Vehicle insurance is no exception, relations in which are associated with the use and exploitation of sources of increased danger. Ultimately, inland transport insurance (property insurance) is an important social guarantee for ensuring the rights of interested parties when they suffer property damage as a result of a road traffic accident. The priority of the interests of the individual, society and the state itself acts as a key factor in the formation of the ideology of the state [2].

Insurance in the context of human-vehicle relationships has a huge impact on ensuring the functioning of the economy, financial stability of participants in insurance legal relationships. The protective function of insurance, aimed at providing protection of the property rights of citizens, organizations, and the state, is the most important aspect of the system of market relations emerging in the Russian Federation. The vehicle insurance, in general, influences the strengthening and stability of the financial platform of the state, provides guarantees for the restoration of the property rights of its citizens, the right to life and health, violated as a result of a road traffic accident. The focus on ensuring the most optimal level of concretization of rights and freedoms is assessed as the duty of the legislator [3].

Maintaining the required level of the vehicle insurance sphere functioning is one of the priority tasks of the state. The special "acuteness" of the issue of vehicle operation safety and road safety in connection with the increase in the number of motor vehicles is noted in the doctrine [4].

Conflicts arising in the field of vehicle insurance regarding the amount of money to be paid to the victim as compensation for damage are not always resolved out of court. Moreover, the dispute often turns into a judicial proceeding, even despite the attempts made by the federal legislator to legislatively update the extrajudicial (pre-trial) procedures for resolving the conflict. The vehicle insurance cases represent a significant volume of civil cases considered and resolved by Russian courts. This publication examines an aspect that is significant in the judicial resolution of such a case, related to the judicial interpretation and interpretation of the text of the insurance contract and insurance rules for the risk of "theft". 


\subsection{Variability of the Judicial Interpretation of the Insurance Contract Text on the Risk of "Theft"}

The use of vehicles is widespread everywhere: most entities not only use such vehicles in business, but also for personal and family needs. The cases of theft (carjacking) of vehicles are not only not decreasing, but are increasing every year. At the same time, when resolving a vehicle insurance case to recover the amount of insurance compensation due to the victim in connection with the theft (carjacking) of a vehicle, the insurance rules and the formulations reflected in it and in the terms of the vehicle insurance contract regarding the risks in case of which the car is insured are important. It often happens that, when the insurance case is adjudicated in court, it turns out that the theft of a car, which is an insured event, does not have the signs of an insured event due to its non-compliance with the features listed in the insurance contract and insurance rules, which entails a court rejection of the victim's claim.

The meaningful characteristics of the term "theft", used by insurers in the text of insurance rules and often significant when an insured event occurs, is subject to the judicial establishment through the prism of concretizing and decoding its essence. In this case, the insured event is considered to have occurred from the moment of application of harm (death, loss, establishment of shortage or damage to the insured property) as a result of the action of the danger against which the insurance was made [5].

The applicable Russian legislator stipulates that the insurance conditions can be spelled out in the terms of the vehicle insurance contract, the insurance rules approved and approved by the insurance company (association of insurers). The obligation for the participants in the insurance legal relationship to comply and fulfill the provisions established in the insurance rules is not diminished, which must be referred to in the text of the vehicle insurance contract. The insurance rules approved by a professional participant in the insurance market is not excluded that may contain provisions that actually exclude circumstances, conditions in an insured event, upon the occurrence of which it is not recognized as an insured event. So, for example, in the text of one judicial act, it is noted that the insurance rules provided for the characteristic of the risk of "theft", which implies the occurrence of an insured event in the form of the loss of an insured car and (or) additional equipment as a result of theft, robbery, robbery (according to the qualifications provided for The Criminal Code of the Russian Federation). In addition, the rules regulate insurance events that are not recognized by the insurance organization as an insured event, including the theft of a vehicle that is not equipped with anti-theft systems, if at the time of the theft of the car they were faulty, dismantled or were in a state that does not allow them to carry out the search function in the volume provided for by the design or anti-theft of the vehicle. In this case, such defects, as provided for by the insurance rules, should have been known to the person allowed to drive the vehicle, either the policyholder or the beneficiary.

Upon these insurance rules, the judicial interpretation of its provisions made it possible to formulate the conclusion that on the part of the insurance company, which established in the insurance policy a condition on the insurance risk as damage and theft and agreed on this condition with the plaintiff, there is a unilateral significant limitation of its obligations under the insurance contract. In particular, the insurer, having regulated additional conditions (circumstances) in the insurance rules, actually excluded theft of a vehicle from the number of insured events, depending on its configuration with a certain type of additional equipment (anti-theft systems) and maintaining it constantly in working order. Since the increase in the grounds for exemption by the insurance organization independently in the text of the insurance rules does not meet the requirements of the current law, the refusal to pay insurance compensation is illegal [6].

It seems that in this case, the insurance company really has established "excessive" requirements for determining insured events that are not an insured event and do not correspond to the requirements of the current law, which in fact indicates the greatest degree 
of interest of the insurer in minimizing the circumstances for which it may be liable under the vehicle insurance contract.

As it follows from the insurance rules of various insurance companies, the issue of attributing specific circumstances that fall and do not fall under insured events is resolved exclusively by them subjectively, and the content characteristic in different insurance organizations is variable in terms of the risk of theft. For example, in one case: "theft" risk insurance implies the occurrence of an insured event, the theft, which means the theft of the insured car, qualified under clauses "b", part 2, Article 158 and "a", part 3, Article 158 of the Criminal Code of the Russian Federation, excluding the insured event, the qualification by law enforcement agencies under other articles of the Criminal Code of the Russian Federation [7]; in other cases theft involves the loss of the insured vehicle and additional equipment as a result of theft, not related to the non-return of the insured car / additional equipment leased (subleased), rental, subleasing (leasing), robbery, robbery, the occurrence of which is confirmed by the relevant documents competent law enforcement authorities [8].

Thus, each insurance organization operating in the Russian Federation invests in the meaningful meaning of the concept of "theft" a variety of freely defined circumstances, on the occurrence of which the recognition of an insured event as an insured event depends, which makes it possible to claim and receive insurance compensation to victims.

The interpretation of the legal texts of the insurance rules and the insurance contract allowed the court, when adjudicating the case, to formulate the conclusion that the description of the insurance risk from which the insurance was made should provide an objective possibility of proving the fact of the occurrence of the insured event at the time of the damage. It is reasonably noted that since damage and death are not identical to the concept of "loss", which includes theft (theft), the validity of the refusal of the insurance company to pay insurance compensation in connection with the loss of the insured cargo is not questioned [9].

In other cases, in view of the fact that the established loss of vehicle owned by the plaintiff as a result of theft has not been refuted, the insurance risk is spelled out in the insurance contract, the court concluded in the text of one of its decrees that the right of a victim to receive the insurance compensation is not can be made dependent on the preliminary criminal-legal qualification of the act, which is reflected in the decision to initiate a criminal case, made by the inquiry authorities. In other words, the court interpreted that regardless of the form and method of theft, as a criminal act referred to in the text of the decision to initiate a criminal case, the victim's right to receive the sum insured or insurance compensation is not diminished and it is possible for implementation, in including by initiating legal proceedings [10].

Otherwise, the court of cassation acting in the territory of the North-Western District of the Russian Federation, leaving unchanged the court rulings on the partial recovery of the amount of insurance compensation in favor of the plaintiff (victim), contrary to the arguments of the insurer's cassation appeal, indicated that the latter, having agreed in the insurance contract the condition with the victim about the insurance risk as theft of the insured property with the specification of the constructive sign of theft (secret theft of property, part 1 of Article 158 of the Criminal Code of the Russian Federation), in fact, did not reflect in the insurance contract text the condition on limiting his obligations on this risk. Having analyzed the terms and conditions of the insurance contract and the insurance rules, the court of cassation found them to be ambiguous, which is not permissible in the provision of financial services to the consumer, which is expressed in not ensuring that the consumer is informed about the limitation of the insurer's obligations on the risk under study, which, in turn, actually deprived the consumer of a financial service has the right to choose it [11]. The judicial practice for interpretation of the insurance rules' provisions and the terms and conditions of the insurance contract, which differs from the above, is formed on the territory 
of the sixth cassation district, the current court of cassation in which (Samara) recognizes the arguments of the victim about the unilateral limitation of the insurer in the rules of insurance of his liability under the auto insurance contract upon occurrence insured event as based on misinterpretation of the current legislation [8].

\section{Results and Discussion}

Since the applicable domestic Russian legislation allows the formulation of the terms and conditions of contractual legal relations by participants in the auto insurance sector independently, it is not actually excluded that the text of the insurance rules and auto insurance contract reflects the subjective discretion of an insurance organization that is a professional participant in the insurance market in comparison with the position of a consumer of financial services. The cited current judicial practice confirms that the discretion of the insurer, as a rule, is aimed at minimizing and reducing the circumstances, formally and meeting the characteristics of an insured event, however, due to the local acts (insurance rules) adopted by it, which are binding on both participants in the insurance legal relationship, they are not such. A meaningful interpretation by the courts of the conditions set out in the insurance rules and the insurance contract, acting in fact as the main "criterion" for formulating a conclusion about the validity of the claims made by the victim for compensation for harm at the risk of "theft", requires a careful approach to assessing this terminological concept used by the participants in the insurance legal relationship. It has been substantiated that justice and legality are ensured by compliance with the current law [12], and the achievement of optimal legal proceedings is possible as a result of the adaptation of the judicial mechanism to the needs of persons applying for judicial protection of their rights [13].

\section{Conclusions}

The judicial interpretation of current insurance rules, the terms and conditions of the vehicle insurance contract, being a complex mental, thinking and intellectual process of the law enforcement officer, is aimed at interpreting, understanding and clarifying the actual meaningful meaning of words and expressions that are used by participants in the insurance legal relationship when concluding an insurance contract. Undoubtedly, the judicial interpretation does not change the really existing conditions in the legal relations of the parties to the insurance conflict, and, moreover, does not create new ones. At the same time, the result of activities on the judicial interpretation of these texts, which is expressed in the corresponding reasoned conclusion of the court, allows him to determine the legality of the insurance company's refusal to pay the victim the amount of insurance compensation and to assess the validity of the claims made by the plaintiff. That is why the arguments of the plaintiffs (victims) about the violation of their rights by the provisions of the insurance rules or the insurance contract require a "vigilant" judicial assessment, putting them in a "disadvantaged" position, expressed in an "unreasonable" preferred approach to minimizing the possibilities of imposing civil law on the insurance company obligations in connection with the occurrence of an insured event recognized as an insured event.

\section{References}

1. Judicial Department at the Supreme Court of the Russian Federation, http://www.cdep.ru/

2. N.A. Taraban, Comparative politics, 3(10) (2019) 
3. Yu.A. Chernysheva, Psychology and law, 9(4) (2019)

4. E.O. Yakovleva, Tomsk state university journal Law, 36 (2020)

5. Rossiyskaya Gazeta, 145, July 5 (2013)

6. Bulletin of the Supreme Court of the Russian Federation, 1, January (2018)

7. The ruling of the Sixth Cassation Court of General Jurisdiction dated March 3, 2020 No. $88-3143 / 2020$, Legal reference system "Consultant plus"

8. The ruling of the First Cassation Court of General Jurisdiction dated September 2, 2020 No. 88-20886/2020, Legal reference system "Consultant plus"

9. A. Bogachev, Yu. Leval, In black and white, Modern insurance technologies, 2 (2017)

10. The ruling of judicial division for civil cases of the Supreme Court of the Russian Federation dated April 21, 2015 No. 18-КГ15-47, Legal reference system "Consultant plus".

11. The ruling of the Third Cassation Court of General Jurisdiction dated June 30, 2020 No. 88-10929/2020, Legal reference system "Consultant plus"

12. L.A. Terekhova, Law enforcement, 3(4) (2020)

13. S. Nikitin, M. Patsatsiya, BRICS law journal, 2(6) (2019) 